\title{
(DE)CONSTRUCTION OF LANGUAGE OF ENVIRONMENTALISM AND RESILIENCE OF THE POOR IN COMMONWEALTH MOVIES: $N O$ MERCY BY OBI OLISA (2016) AND THE LIQUID BLACK GOLD BY IKENNA EMMA (2013).
}

\author{
Afutendem Lucas Nkwetta \\ University of Dschang, Research Centre in Space, Arts and Humanities (CEREAH) \\ Research Group in English and Commonwealth Studies
}

\begin{abstract}
This paper examines and deconstructs the language of environmentalism and resilience of the poor in No Mercy by Obi Olisa (2016) and The Liquid Black Gold by Ikenna Emma; all produced in Nigeria, a member of the Commonwealth. It showcases the role the poor play in fighting to protect the environment and mitigate climate change. We examine English language use in issues related to environment; which are of paramount importance to Commonwealth states, communities and the world at large. We analyze the soft power strategies used in managing or coping with environmental challenges. How can the media be used to promote environmentalism of the poor in the Commonwealth? How can the grassroots be brought into environmental discourse and decision making process? What language is suitable for understanding the issues surrounding the environment? The hypotheses are that movies can effectively be integrated into the environmental discourses and in bringing rural poor to play active roles in raising of awareness on environment resilience. We used the Theory of Deconstruction by Jacques Derrida (1967), Semiotics and the Speech Act Theory; Deconstruction enabled us to critique the relationship between texts and meanings. Analyses and results show a mastery of the aptness of using movies in raising awareness and getting involvement in environmental related phenomena. The results suggest that transdisciplinary environmental education is prior and necessary for individuals to increase their awareness and to develop abilities to reflect on their environmental responsibilities.
\end{abstract}

Keywords: media, language, Commonwealth, soft power, deconstruction, environmentalism, resilience.

\section{INTRODUCTION/BACKGROUND}




\section{International Journal of Arts and Humanities}

ISSN: 2581-3102

Volume: 04, Issue: 01 "January 2020"

It is generally agreed that change can come about if people develop positive attitudes. In this regard it is clear that the need for education to make people aware of their negative impacts on nature could only be realized through effective environmental education in primary, secondary, tertiary and higher levels and both in formal and non-formal settings as stated in the 10 Point Action Plan of the Tallories Declaration of the Association of University Leaders for a sustainable Future (ULSF, 1990).

$\mathrm{t}$ is believed that individualse socio-demographic attributes such as gender, age, education type and level, environmental education, nature connectedness, family structure, religious beliefs, political preferences, (family) income, country, ethnicity along with many other variables may have an influence on their attitudes towards environmental issues in varying degrees. However, age, gender and educational concerns (such as education type and level, scientific knowledge) have been the most studied variables predicting people ${ }^{\text {ee }}$ s environmental concern.

An environmentalist is a supporter of the goals of the environmental movement, "a political and ethical movement that seeks to improve and protect the quality of the natural environment through changes to environmentally harmful human activities". In a post-modern world reality has become fluid, and no medium has done more to it so than movies, with its wide accessibility, its sense-and-psyche altering format, and its effortless ability for persuasion. The study of media today is inevitable in linguistics given that it has transformed the world into 'a global village' (Marshal Mc Luhan) wherein notions like borders and distance between countries no longer exist, since one can easily be in his room in a corner in Cameroon. As climate change is projected to hit the poorest the hardest, it is especially important for experts to pay particular attention to the management of traditional and cultural practices that depend solely on the environment. If rural communities are to respond adequately to climate changes, they will likely need help assessing their risks and vulnerabilities, prioritizing and coordinating projects and deploying information-sharing and decision support tools. Nowadays, adaptation has become a key focus of the scientific and policy-making communities and is a major area of discussion in the multilateral climate change process. This study is of significance to all stake holders involved in environmental and climate change related issues. Secondly, policy makers will find this study helpful in formulating policies and program to promote proactive film production for nation image building and preservation of local cultural and environmental heritage. Impacts due to climate change cross culture, community and regional lines, making solutions dependent upon meaningful participation of numerous stakeholders from state, local, and traditional authorities, science and academia, the private sector, non-profit organizations, and the general public. Effective adaptation measures are closely tied to specific local conditions and needs and take into account existing social networks. 
International Journal of Arts and Humanities

ISSN: 2581-3102

Volume: 04, Issue: 01 "January 2020"

Nigeria is a West African Commonwealth nation with an estimated 210 million population. It shares land borders with the Republic of Benin in the West, Chad and Cameroon in the East, and Niger in the North. Nigeria's coast lies on the Gulf of Guinea in the South and it borders Lake Chad to the North East. The Federal Republic of Nigeria, named for River Niger is the most populous country in Africa. Nigeria became an independent state in 1960 after gaining its sovereignty from the United Kingdom. Nigeria joined on $1^{\text {st }}$ October 1960. Nigeria was suspended in 1995 and the suspension was lifted in 1999. As a member of the Commonwealth, it needs to respect the core values and principles of the association, one of which is the preservation of African values, culture and environment. Nigerians through most of their films have been portraying their culture both at home and to the world. The first Nigerian films were made by filmmakers such as Ola Balogun and Hubert Ogunde in the 1960s, but they were frustrated by the high cost of film production. Nollywood, the Nigerian video film industry, is an unlikely success story. Nollywood has grown to become the world's second highest producer of films today and they produce 50 original Nigerian films. In the space of one month, Nollywood produces 150 films and the government of Nigeria is doing everything to encourage the company. Nollywood is an industry that has high turnover and challenges the western mode of storytelling. The company also employs a large number of citizens with government or foreign aid, making it also a second largest industry by number of employees in the country.

In a mere two decades, Nollywood has become one of the world's most important creative industries. It has been an explosive commercial success with vast numbers of videos available in shops and on street corners throughout Africa and especially in Cameroon.

Nigerian films are deeply rooted in Nigerian cultural traditions and social texts that focus on Nigerian community life. Nigerian stories are told using African idioms, proverbs, costumes, artifacts, cultural display, and the imagery of Africa. The common Nollywood genres include horror, comedy, urban legend, mythic parable, love and romance, juju, witchcraft, melodrama, and historical epic. Movie production helps to determine the differences and transformations that have occurred in Nigeria.

Environmentalism is a broad philosophy, ideology and social movement which began in the 1800s regarding concerns for environmental protection and improvement of the environment on humans, animals, plants and non-living matter. Environmentalism advocates the preservation, restoration and improvement of the natural environment and may be referred to as a movement to control pollution and protect plant and animal diversity. For this reason, concepts such as land ethnic, environmental ethics, biodiversity, ecology and the biophilia hypothesis figure are predominant. 
International Journal of Arts and Humanities

ISSN: 2581-3102

Volume: 04, Issue: 01 "January 2020"

The environmentalism of the poor manifest itself through conflicts that have an ecological element, including social justice claims and involving impoverished populations struggling against the state or against private companies that threaten their livelihood, health, culture and autonomy. These movements are born from the resistance (expressed in many different languages) against the disproportionate use of environmental resources and services by the rich and powerful people. In environmentalism of the poor, the poor people lack social facilities such as: education, health service, good water and good infrastructures. In environment is poor and their way of reasoning too is poor due to lack of educational knowledge as well as their houses. In environmentalism of the poor, men, women and children strive to correct the wrongs that have been committed against the land, water, air and every other thing in their environment. In the course of doing this, they contradict the Brundtland report and its view that environmental damage is caused by poverty.

The main academic causes of the environmentalism of the poor are, ecological anthropology, agro-ecology and political ecology. Some examples of the environmentalism of the poor are: The Ogoni, the Ijaw and other groups protesting the damage from oil extraction by Shell on the Niger Delta, resistance against eucalyptus in Thailand and every other place in the grounds that plantations are not forest, the movement of oustees due to dam construction as in the Narmada river in India , the antigods' porbarragens in Brazil and the new peasant movement such as via Campesina, against agro-industries and bio piracy (the appropriation of knowledge of agricultural or medicinal plant without payment).

Environmentalism is a broad philosophy, ideology and social movement that was coined in 1922 regarding concerns for environmental protection and improvement of the health of the environment, particularly as the measures for this health seeks to incorporate the impact of changes to the environment on humans, animal, plants and non-living matter. Environmentalism focuses on the environmental and nature-related of green ideology and politics while ecologism combines the idea of social ecology and environmentalism. 'Ecologism' is used more in continental European languages while 'environmentalism' is commonly used in English more but the words have slightly different connotations.

John Ruskin, an influential thinker articulated the Romantic idea of environmental protection and conservation. Systematic efforts on behave of environment only began by the late $19^{\text {th }}$ century. It grew out of the amenity movement in Britain in the 1970s which was a reaction to industrialization, the growth of cities and worsening air and water pollution. Starting with the formation of the common preservation society in 1965, the movement championed rural preservation against the encroachment of industrialization. 
International Journal of Arts and Humanities

ISSN: 2581-3102

Volume: 04, Issue: 01 "January 2020"

Deconstruction is a critique of the relationship between text and meaning originated by the philosopher Jacques Derrida. His approach consisted in including reading of the texts with an ear to what runs counter to the intended meaning or structural unity of a particular text. The purpose of deconstruction is to expose that the object of language and that which any text is founded upon, is irreducibly complex, unstable or impossible.

\section{PROBLEM STATEMENT, QUESTIONS, HYPOTHESES AND SIGNIFICANCE}

Environmental stress has often been seen as the result of the growing demand on scarce resources and the pollution generated by the rising living standards of the relatively affluent. 'But poverty itself pollutes the environment, creating environmental stress in a different way. Those who are poor and hungry will often destroy their immediate environment in order to survive'. (Robin Broad, 1994) They will cut down forests; their livestock will overgraze grasslands; they will crowd into congested cities. Thomas Malthus indirectly suggested that the poor are more likely to engage in environmentally deleterious behavior because they are incapable of thinking beyond the next meal. Still there is often a mainstream belief that for poor countries to develop, environmental concerns have to be sacrificed, or is a luxury to address once poverty is alleviated. The cumulative effect of these changes is so far-reaching as to make poverty itself a major global scourge. In other words, poverty or poor people are viewed as one of the primary causes of environmental destruction; the poor may be the victims, but so too are they the agents, the perpetrators.

On the contrary, environmentalism here is linked to the leadership role the poor can play in mainstreaming environmental issues. When we watch films with a critical mind, we realized that they are always configured respectively to societal classes. How can the media be used to promote environmentalism of the poor in the Commonwealth? How can the grassroots population be brought into environmental discourse and decision making process? What language is suitable for understanding the issues surrounding the environment? The hypotheses are that Movies can effectively be integrated into the environmental discourses; the issues related to environment can be handled better by bringing rural poor into the movies and language choice and use are pre-requisites for proper raising of awareness on environment resilience.

Jacques Derrida in his book of Grammatology (1967) introduced the majority of ideas influential within deconstruction. According to him and taking inspiration from the work of Ferdinand de Saussure, language as a system of sign and words.

Harold Bloom in a 1983 interview with Robert Moyniham said, "what I think I have in common with the school of deconstruction is the mode of negative thinking or negative awareness, in the technical, philosophical sense of negative, but which comes to me through negative theology... 
International Journal of Arts and Humanities

ISSN: 2581-3102

Volume: 04, Issue: 01 "January 2020"

there is no escape, there is simply the given, and there is nothing that we can do." in accordance, Slavoj Zizek has identified the mid to late 1980s as the period when Derrida's deconstruction shifted from a radical negative theology to a Kantain idealism.

In 1989, Bloom eschewed any identification with the Yale School's technical, methodological approach to literary criticism. He stated that "there is no method except yourself" and observed that deconstruction as a mode of thought is best understood as unique to Derrida. In a 2003 interview, Bloom recalled that in his past, he found himself "fighting" deconstructionist. In the same interview, he stated that the deconstructionist were his friends and that what interest him in language is the absolute, a notion he shared with Yale School deconstructionists and the negative theology of Kabbalsts.

Social or environmental movements consist of a large number of people who organize themselves to promote or resist social change. Social movements can be either proactive to promote social change or proactive to resist any social change. Sidney Tarrow (1994:3-4) sees social movements as "collective challenges by people with common purpose and solidarity in sustained interaction with elites, opponents and authorities. According to him, social movements or environmental arise from widespread deeply left discontent, from the conviction that some condition of society is no longer tolerable, "environmentalism of the poor" proliferates.

Environmental justice as an organized movement has been almost confined to its "country of origin"- the United States, while popular environmentalism or livelihood ecology or the "Environmentalism of the poor" are names given to the myriad of movement in global south that struggle against environmental impact that threaten the poor people who are in many countries, a majority of the population (Martinez-Alier 2008). Environmentalism of the south is always given the title of the "Environmentalism of the poor" since the people of the global south have by and large, been victims of the growth-centric development approach and the environmental food prints and it is the poor people who have organized environmental movements in the south (Guha and Martinez-Alier1997).

To quote from McMichael (2008: 245) the environmentalism of the poor "takes two forms: active resistance, which seems to curb invasion of habitats by states and markets; and adoptions, which exemplifies the century's old practice of reviewing habitats in the face of environmental deterioration .in the alter practice lies some answers to current problems."

As far as environmentalism is concern, first, a complex relationship exists between the variables of environmental pollution and economic growth as well as among the variables of environmental pollution Akinyemi et al (2017). Second, environmental quality is a luxury public good which the poor who bear the brunt of environmental pollution can hardly afford (Anantha, 
International Journal of Arts and Humanities

ISSN: 2581-3102

Volume: 04, Issue: 01 "January 2020"

1996, Ananthan and 2006). Also, environmental pollution places stress on natural resources and social infrastructure which may eventually results in conflict, arm struggle, imagination and other social vices in detriment to the desired economic growth (united nations research institute for social development (UNRISD), 1994).

The above writers have all written something in relation to the deconstruction and environmentalism of the poor but they have not talked about environmentalism of the poor in the Nigerian community. My focus then Is to show the environmentalism of the poor in the Nigerian community.

\section{LITERATURE REVIEW AND THEORETICAL FRAMEWORK}

Despite the fact that Common European Framework (CEF) (Trim, North, Coste, \& Sheils et al. 2001) suggests "environment" and "nature" as everyday language teaching topics and movies, including documentaries, as common materials, they are still not considered ascanonic parts of language teaching in Turkey, and even in many developed countries for foreign language teachers and educational institutions (Leitzke-Ungerer, 2009; Thaler 2007) due to the lack of a number of instructional, physical, financial, logistical etc. factors (Leitzke-Ungerer, 2009; Wilts 2001). Studies on the use of film material in foreign language education (FLE) showsthat feature films are dominantly preferred for the exchange of intercultural values (Gieselmann, 2010; Schwerdtfeger, 1989). In fact the potentials of the documentary movies, such as increasing (environmental) values and attitudes besides developing linguistic skills are accepted theoretically and suggested by many researchers (Kuchler, 2009; Thaler 2007) and language institutions, for example, CEF (Trim et al., 2001); however, studies investigating the implementation of such materials in this field still lacks. The study believes, like this one that important actors of educating "for environmentally responsible citizenship" and "fostering environmental literacy for all by using every opportunity", as stated in the Tallories Action Plan (ULSF, 1990).

The use of several modern film making techniques to portray various societal issues has succeeded in capturing the interest of a large interest. As a result, the way these societal issues are represented in movies has acquired a great interest in the scientific milieu. Among the most discussed of these societal issues resides the construction of the environment of the poor. In Cameroon, as in many other Sub-Saharan Africa countries, climate change is just an added stress to a range of other pressures, some of which are currently more pressing than climate change. Pressures such as forest fragmentation, reduction in habitat and the resulting adverse effects on wildlife species are already proving difficult to manage. Inappropriate land use practices have led to increased deforestation and forest degradation, soil erosion, flooding of low lying areas and the destruction of watersheds. It is very likely that even more modest losses in biodiversity 
International Journal of Arts and Humanities

ISSN: 2581-3102

Volume: 04, Issue: 01 "January 2020"

would cause consequential changes in ecosystem goods and services (Arnell 2004; IPCC 2007; Dai et al. 2009).

From the formalist framework that refers to critical approaches that analyze, interpret, or evaluate the inherent features of a text.

The question of language, culture, environmental and climate change discourse is a topical issue as is shown by the numerous publications on the subject during the last few years. However few publications lay emphasis on cultural issues considered to be particularly exposed to the problem of climate change (by location or by activity) and on the impact of sensitization on these beliefs. Africa is one of the most vulnerable regions in the world (OSS/UNEP, 2010). The impacts of climate change are considered the most serious (IPCC, 1998). The African continent is also the most affected by the ongoing and future climate change (NECTAR, 2012). In fact, Africa is facing serious effects of climate variability and extreme events such as droughts, floods and storms which are likely to increase both in frequency and intensity. The levels and patterns of rainfall may change.

\section{Theoretical Framework}

We used the Theory of Deconstruction by Jacques Derrida (1967), Semiotics and the Speech Act Theory; Deconstruction enables us to critique the relationship between text and meaning. This approach consisted of conducting reading of text with an ear to what runs counter to the intended meaning or structural unity of two films. According to Derrida and taking inspiration from the work of Ferdinand de Saussure, language as a system of signs and words only has meaning because of the contrast between these signs. As Rorty contends, "words have meanings only because of the contrast-effects with other words... no word can acquire meaning in the way in which philosophers from Aristotle to Bertrand Arthur William Russel have hoped it might by being the unmediated of some non- linguistic. As a consequence, meaning is never present but rather; it is differed to other signs; Derrida then beliefs that a concept must be understood in the context of its opposite such as being/ nothingness, normal/abnormal or speech/writing.

To "deconstruct" an opposition is to explore the tensions and the contradictions between the hierarchical ordering assumed (and sometimes explicitly asserted) in the text's meaning, especially those that are indirect or implicit uses of language.

This theory is complemented with Semiotics which was founded by Charles Sanders Peirce in connection with Ferdinand de Saussure's semiology (1950s and 1960s). It is a study which involves the cooperation of three subjects: sign, object and its interpretant. It will also be analyzed using semiotics. This theory was propounded by C. S (1839-1914 Peirce and Ferdinand de Saussure (1857-1913). It focuses on the production and interpretation of meaning. Its basic 


\section{International Journal of Arts and Humanities}

ISSN: 2581-3102

Volume: 04, Issue: 01 "January 2020"

principle is that meaning is made by the deployment of acts and objects which functions as signs. The theory also emphasizes multimedia. Multimedia semiotics is based on the principle that all meaning-making, because it is a material process as well as a semiotic practice, necessarily overflows the analytical boundaries between distinct, idealized semiotic resources such as language, gesture, depiction and action.

The symbol is a sign that denotes its object solely by virtue of the fact that it will be interpreted to do so. For Peirce, every symbol is a general and that which we call an actual individual symbol is called by Peirce a replica or instance of the symbol.

Peirce conceives of and discusses things like representations, interpretations and assertions broads, and in terms of philosophical logic, rather than in terms of psychology, linguistics or social studies.

Another theory suitable for this research work is the theory of environmentalism.

The above mentioned theories are suitable for this research because Jacques Derrida's theory of deconstruction gives us a critical mind when studying environmentalism. The semiotic theory also helps us to be able to analyze images and the theory of environmentalism threats environmental issues. As such, we are going to use these three theories to deconstruct environmentalism of the poor in the Nollywood film No Mercy.

Since we had to analyse the spoken word used in the dialogues in the film, we picked the speech act theory. Speech act theory is built on the foundation laid by Wittgenstein and Austin (1975). John Searle (1969) is most often associated with the theory. Wittgenstein began a line of thought called 'ordinary language philosophy'. He taught that the meaning of language depends on its actual use. Language, as used in ordinary life, is a language game because it consists of rules. In other words, people follow rules to do things with the language. According to Searle (1969), to understand language one must understand the speaker's intention. Since language is intentional behavior, it should be treated like a form of action. Thus Searle refers to statements as speech acts. The speech act is the basic unit of language used to express meaning, an utterance that expresses an intention.

Normally, the speech act is a sentence, but it can be a word or phrase as long as it follows the rules necessary to accomplish the intention. When one speaks, one performs an act. Speech is not just used to designate something, it actually does something. Speech act stresses the intent of the act as a whole. According to Searle, understanding the speaker's intention is essential to capture the meaning. Without the speaker's intention, it is impossible to understand the words as a speech act. There are four types of speech act: utterance acts, propositional acts (referring is a type of propositional act), illocutionary acts (promises, questions and commands) and 
International Journal of Arts and Humanities

ISSN: 2581-3102

Volume: 04, Issue: 01 "January 2020"

elocutionary acts. An elocutionary act can be used to elicit some behavioral response from the listener. Searle believes that speakers perform acts by observing two types of rules: constitutive rules or definition rules (create or define new forms of behavior) and regulative or behavior rules (these rules govern types of behavior that already exist). Speech act theory has contributed to the rules perspective in communication because it provides a basis for examining what happens when speakers use different definition and behavior rules. By analyzing the rules used by each speaker, researchers can better understand why conversational misunderstandings have occurred.

This theory goes in line with this article in the sense that, sensitization on the preservation of natural resources is not well understood by the audience. They are not given options to cover up for what is being said, therefore influencing their behaviors or thinking; seeing more of the negative impact of climate change.

\section{THE SUMMARY OF THE LIQUID BLACK GOLD DIRECTED BY IKENNA EMMA.}

The Liquid Black Gold directed by Ikenna Emma is a Nigerian film which talks about the socioeconomic hardship of Nzekede community, destroyed by the rich with oil mining activities. The farm land is destroyed and the only source of drinking water for the community is polluted. They have been exploited, their sexually abused while the so called elites the elected to represent them and their interest before the government and the white men and their oil company are living luxuries life. The used the money allocates for compensation to the community and community projects for their personal interest. Out of frustrations, the youths of the community organized themselves to revolt against the atrocities of the oil company; the government reacted by arresting, jailed and killed some of them.

This result into a full crises the youth was split into two one which is the genuine youth group who fight to defend their community interest and the other formed by the greedy elites to protect their personal interest. The genuine youth group resists the intimidation and humiliations from the power that be until they achieved their objectives, which is life returned to it normalcy road was constructed, employments for the youths, good drinking and social amenities for the community was assured by the oil company.

The film begins in Ebipade's house the genuine youth group leader who is explaining his wife and son the reason they picked up arms against their oppressors is to kill but to fight to live and demand for in their change in their community which the white men and their oil company has destroyed. It ended when both parties come to term with each others.

\section{Summary of the Nollywood Film No Mercy by Obi Olisa}


The film No Mercy is divided into 6 parts, but we are going to do our analysis from 3 parts. That is, part 1, 2 and 3. The film is about a village community Umuatu, where the people lived happily until when Atuegu came with an offer to buy their community land. The people of Umuetu demanded for five hundred thousand but Atuegu gave them ten million. The villagers become excited, little did they know that Atuegu had discovered crude oil on their land and wanted to exploit it. Breye educates the villagers that Chief Atuegu wants to buy their land because he has discovered crude oil. The villagers then decide not to sell their land again. Atuegu decides to take the land by force. Atuegu begins to kill the villagers but the villagers decide to run into the village forest. He kills many villagers and even follows them in the forest and kill them there too. The whole villages become polluted with corpses lying everywhere in the village and the forest. In the course of the killing, Atuegu destroys many trees, food crops and leaves with bullets. All these things force the villagers to organize themselves in groups and fight against the environmental destruction of their land by Atuegu and to take back the village from him. At the end of part three, he kills two girls beside the river in Akeke forest and left their corpses besides that river because the other villages refuse to come out and bow to him.

\section{Analyses of findings}

The findings of this research work will be done using part one, part two and part three of the Nollywood film No Mercy by Obi Olisa to deconstruct environmentalism of poor in the Nigerian community.

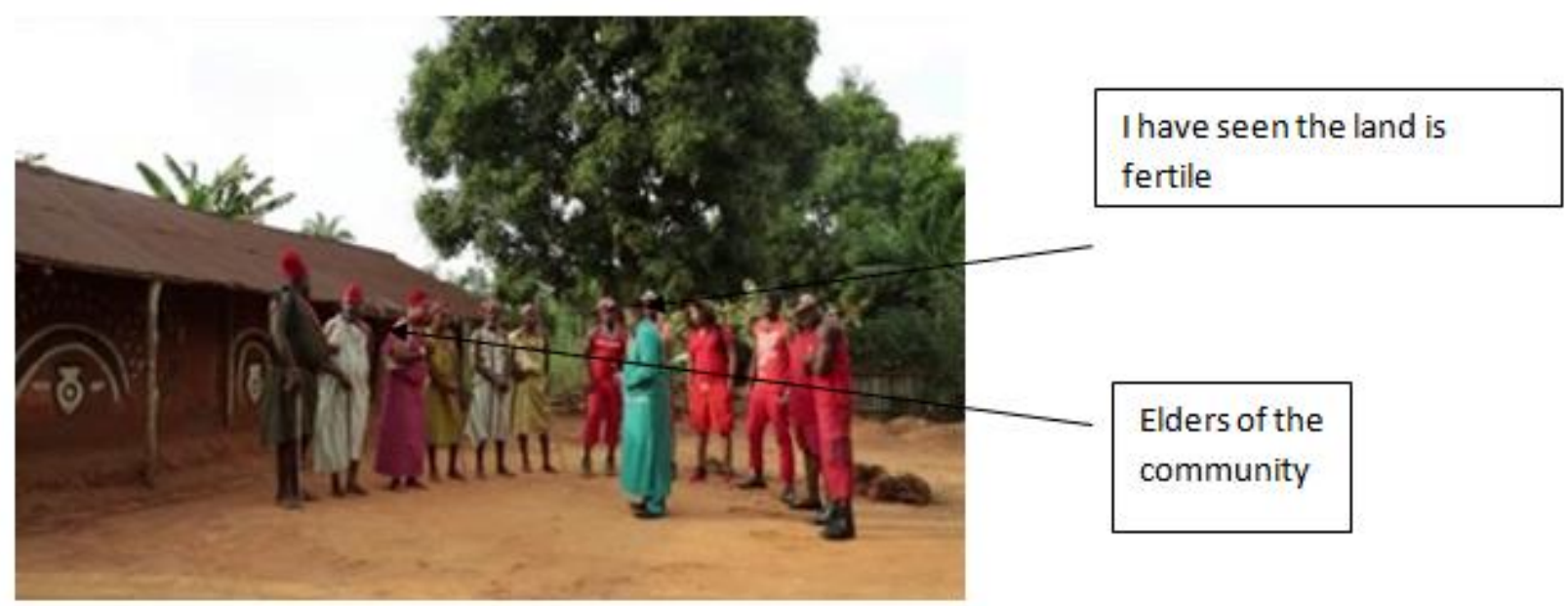

\section{Obi Olisa's No Mercy part one (18:15): the palace}

The issue of brain washing is one aspect of the environmentalism of the poor that we are going to deconstruct in the film. The image above is an instance of brain was Chief Atuegu is brainwashing the villagers to sell their community land to him. He deceives the villagers that he 


\section{International Journal of Arts and Humanities}

ISSN: 2581-3102

Volume: 04, Issue: 01 "January 2020"

is a philanthropist who is a rich man who helps the poor and those in need but Atuegu is completely opposite because his interest is to exploit the villagers. Atuegu say, "I have seen that land is fertile" and "I want to start farming in a bigger way" He deceives the people with this words and tells them that he is going to empower the youths of the community to work in the land and that he will invite the government into the land and the government will then develop the community by opening schools, hospitals and construct a community town hall. The producer uses this instance of brain wash through Atuegu to show how the government or private individuals brainwash the poor people when they want to exploit their land.

In the course of the discussion in the image, Atuegu says "I want to start farming in a bigger way." Farming is one of the reasons of environmentalism. Since environmentalism of the poor is out to denounce the destruction of their natural environment, farming becomes a threat to them because in the course of farming, threes will be cut down, grass cleared and tilling of the soil too is involve. All this things expose the land to sunlight which can cause climate change which in turn leads to drought in the dry seasons. In periods of rainfall, the soil becomes light, leading to soil erosion. When we look at the image, we see Atuegu's men dressed in red which is a sign and symbol of danger for the land because red normally, is a color that represents danger. Any community that discovers these threads on their land, they are force to revolt.

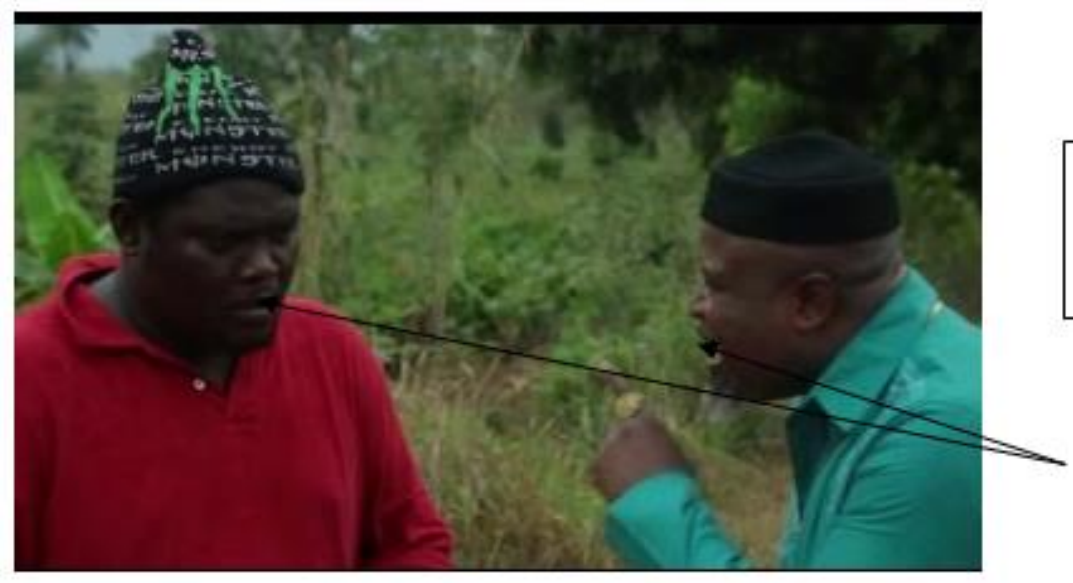

"I hope $u$ included the benefits that my family is going to get from the oil company"

"No sir, no sir, what I included is the benefits the community will get in the case of any environmental hazzard"

\section{Obi Olisa's No Mercy part one (24: 20): village road}

Environmentalism of the poor also fights against exploitation of resources by the government or private individuals. In the film No Mercy, Chief Atuegu intends to extract crude oil from the village community land and enjoy the benefits with his family. In the image above, chief Atuegu inquire from Breye, "I hope you included the benefits that my family will get from the oil company" and Breye replies, "no sir, no sir, what I included is the benefits the community will 


\section{International Journal of Arts and Humanities}

ISSN: 2581-3102

Volume: 04, Issue: 01 "January 2020"

get in the case of any environmental assize." In the image, we see him pointing his finger at Breye to and this shows his angers towards Breye who is trying to frustrate his plans of destroying the land. This communication also shows the extravagance and materialistic nature of the rich people whose interests is to exploit the resources of the poor to get richer while the poor people become poorer even with all the natural resources that they have. When the villagers finally learn of Atueugu's plans, they had to resist him to protect their land from being destroyed.

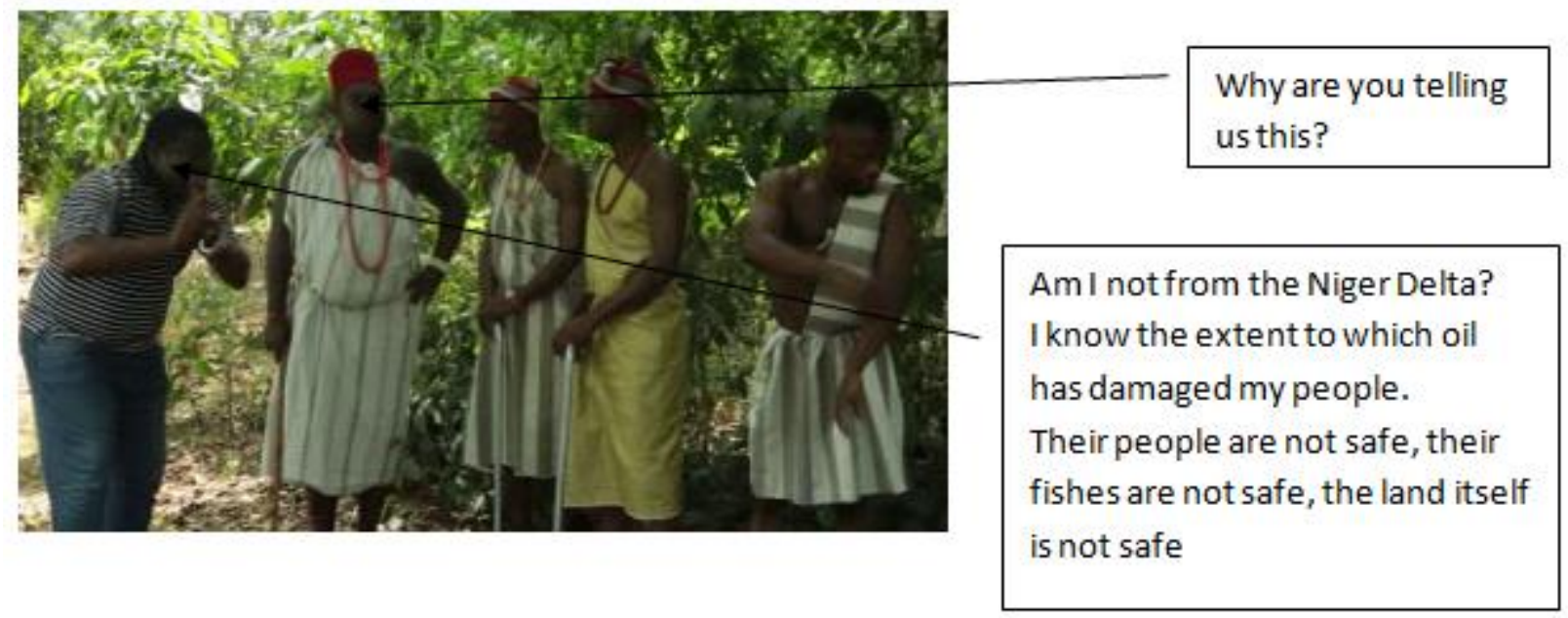

\section{Obi Olisa's No Mercy part one (31: 30): village farm}

Environmentalism of the poor is also out to denounce pollution of the natural environment of the poor. In the movie No Mercy, when Breye discovers that Atuegu wants to extract the oil alone without minding the effect of its pollution on the village community, he decides to educate the villagers on the danger that awaits them if Atuegu extracts the oil. In the image, he explains to the chiefs of the land and some elders that their community will not be safe if they sell their land to Atuegu because the oil will pollute the land. He explains that he is from the Niger Delta and he knows the extent to which oil has damage his people. He says "the people are not safe, their fishes are not safe and the land itself is not safe." This means that the oil extraction is something that can cause untold pollution on the Umuatu village. The producer in this instance brings an aspect of reality through Beye who talks about the effect of oil in the Niger Delta. The Ogoni and the Ijaw are examples of clans that have suffered and resisted oil extraction in the Niger Delta.

Still in the image, Breye talks about how Atuegu discovered that there is crude oil on the land as he says, "six months ago, Umuatu village sold logs of wood to Chief Atuegu and when the men were working under site, the white man in charge of the operation discovered crude oil gorging out from that land." The fact that the people of Umuatu sold logs of wood was a form of environmental destruction because Atuegu had to fell down tress in order to get the $\operatorname{logs}$ of 
wood. The idea of felling down tress for wood is a form of environmental destruction because it leads to deforestation and deforestation leads to high leaching which can cause soil erosion. Deforestation can also cause climate change and climate change can lead to drought and as such, the people strive to resist further destruction of their resources in order to prevent the above mentioned effect on their environments. The producer presents this instance to show the society that the felling down of tress does not only cause leaching, but that it can also lead to other discoveries that can damage the environment if exploited.

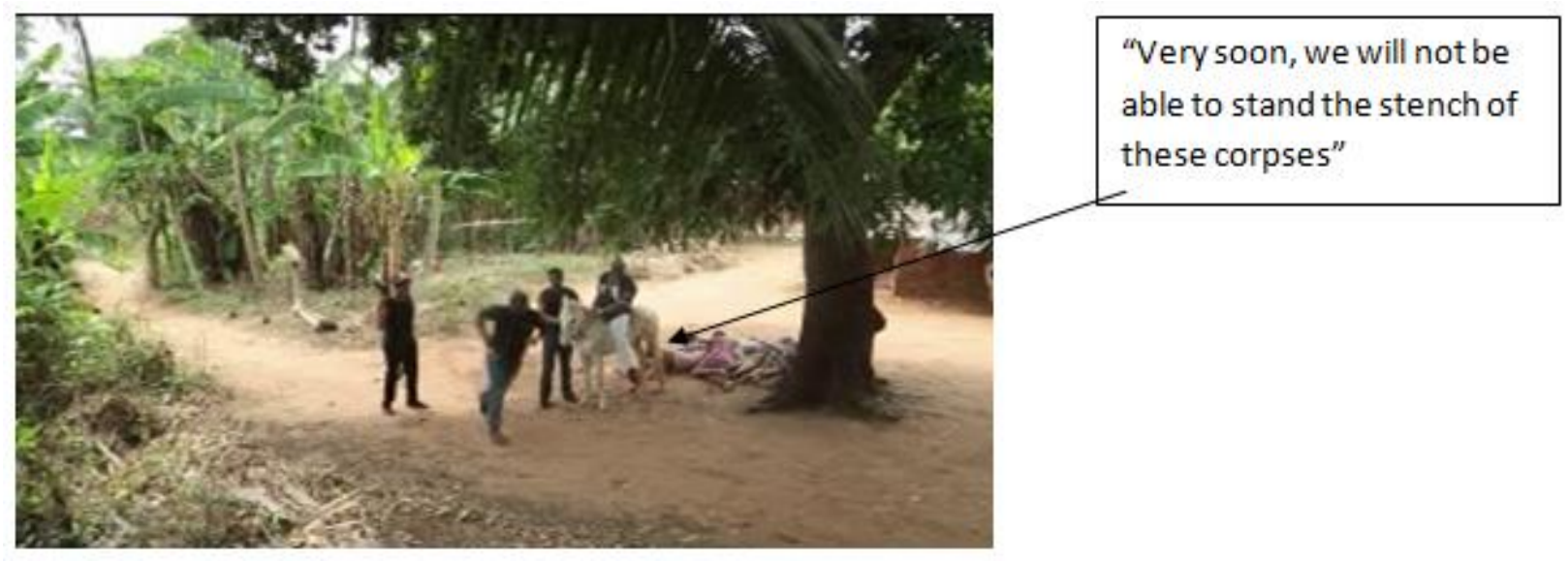

Obi Olisa's No Mercy part 3 (41:00), village street

As we said above, environmentalism of the poor also aims at denouncing the environmental pollution of the community of the poor. The pollution in the movie No Mercy is not just about the oil extraction but also about human beings. When the villagers discover Atuegu's plans to exploit their resources to his own benefits, they decide to resist him but since Atuegu cannot welcome resistance, he decide to kill the villagers. The image shows corpses lying everywhere in the village. Corpses are littered at the village streets, in the farms, at their homes and in the forest and nobody cares to bury them. These corpses are a form of pollution as they are left unburied and when they get rotten, the stench causes pollution. This is evident in the film when Breye says "very soon, we will not be able to stand the stench of these corpses, I am trying to arrange a mass burial for them", but his master says, "you don't mix evil with good. If you want to be bad, be bad... live them to rotten here, I don't care." When we look at the image, we see that the corpses are lying under a tree and because trees need carbon dioxide to grow, Atuegu prefers that if the villagers will not allow him to destroy their environment, he will kill them and use their corpses as manure for the trees. 


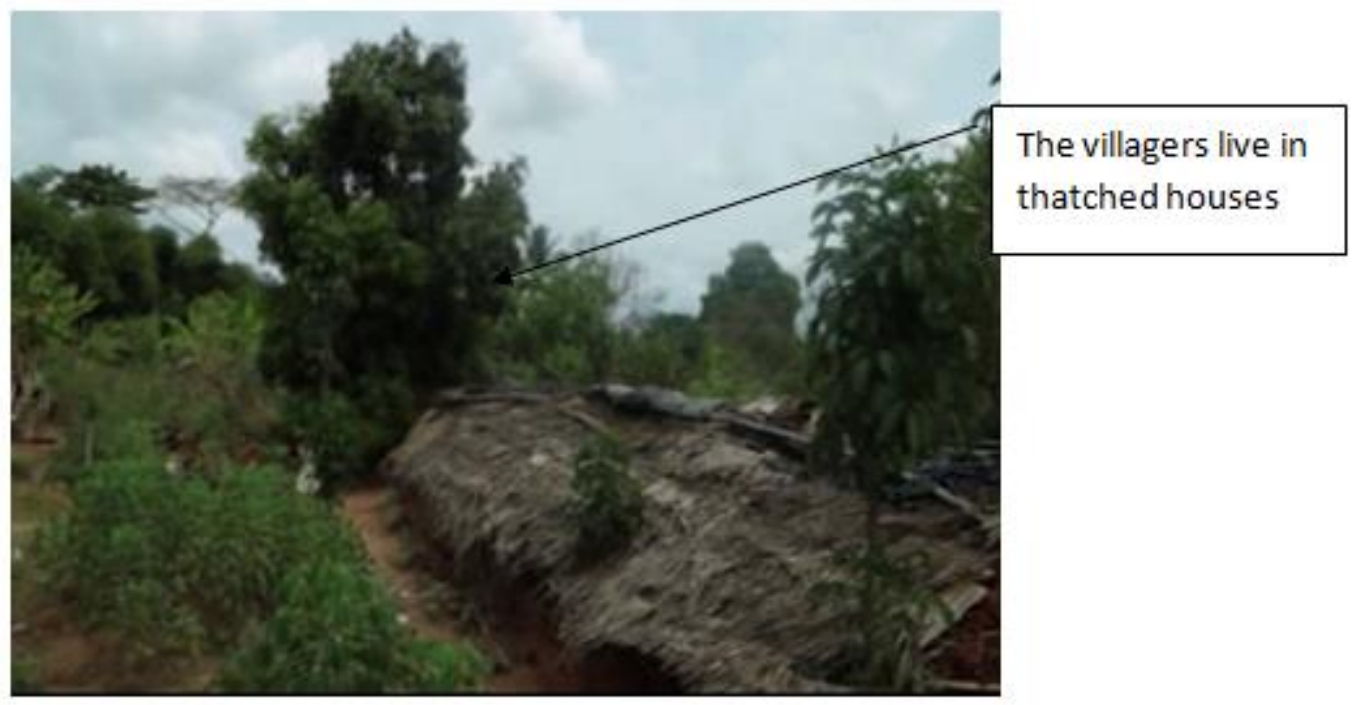

Obi Olisa's No Mercy part two (49:40): village house

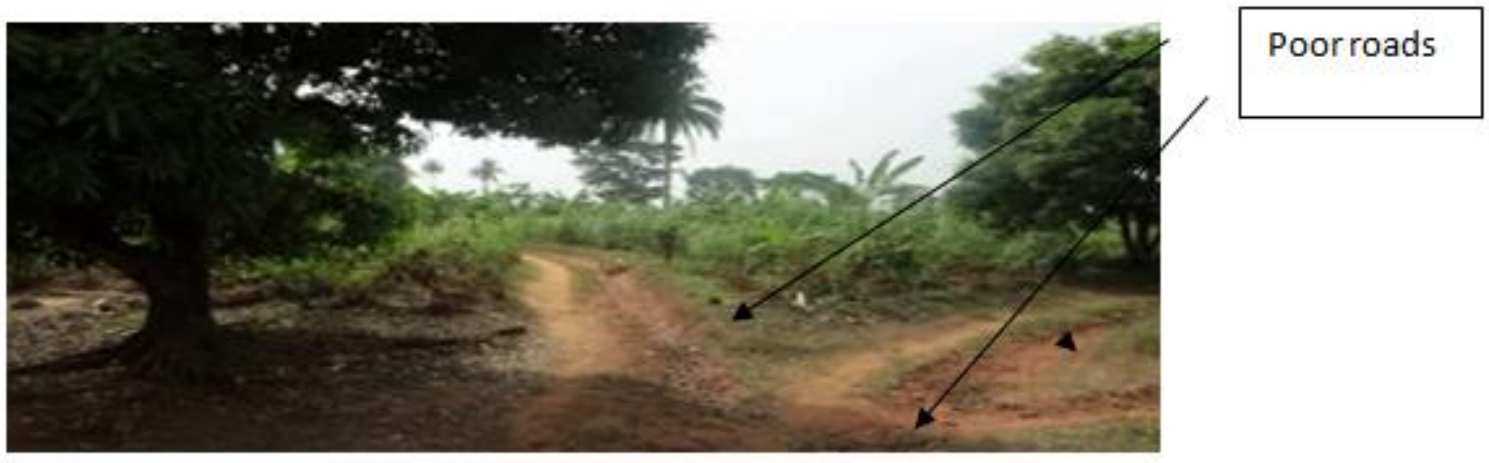

\section{Obi Olisa's No Mercy par two (29:00): village road}

The setting of the film is in a rural community. When we look at the image, we see traces of poverty through their houses, their, their way of dressing; their roads and the kind of language that they speak and this are some of the causes of the environmentalism of the poor. The roads in Umuatu village are mostly footpaths. They live in thatched houses, built with mud bricks, and roofed with grass. Their way of dressing also shows the kind of environment that they come from. The villagers do not have good clothes to wear and they dress exposing parts of their bodies. The chief's dressing is not different from that of his king's men. The people speak English, mixed with their mother's tongue. All these things are aspect of a poor environment and the lack of good roads, good houses, good roads and schools to educate them causes resistance for social claims. The villagers are forced to resist against Atuegu so that they can work directly 
with the oil company in order to enjoy the social facilities that will come with the oil company. The producer brings in their mother's tongue in the film in order to promote their culture to other parts of the world.

The setting of part two and three of the film is mostly in their natural environment where there are trees and grass around. The trees and grass are environmental aspects that serve as a source of livelihood to the people of Umuatu village because they run away from Atuegu's and his men and hide there. The village has different species of trees that beautifies the land and protects the environment from facing climate change and prevens their water from getting dry. They also protect the land from facing drought and soil erosion. Atuegu and his men fires gun shots on the trees and leaves, thereby causing damage to the trees, hence the villagers strive to take their land from Atuegu in order to preserve their trees.

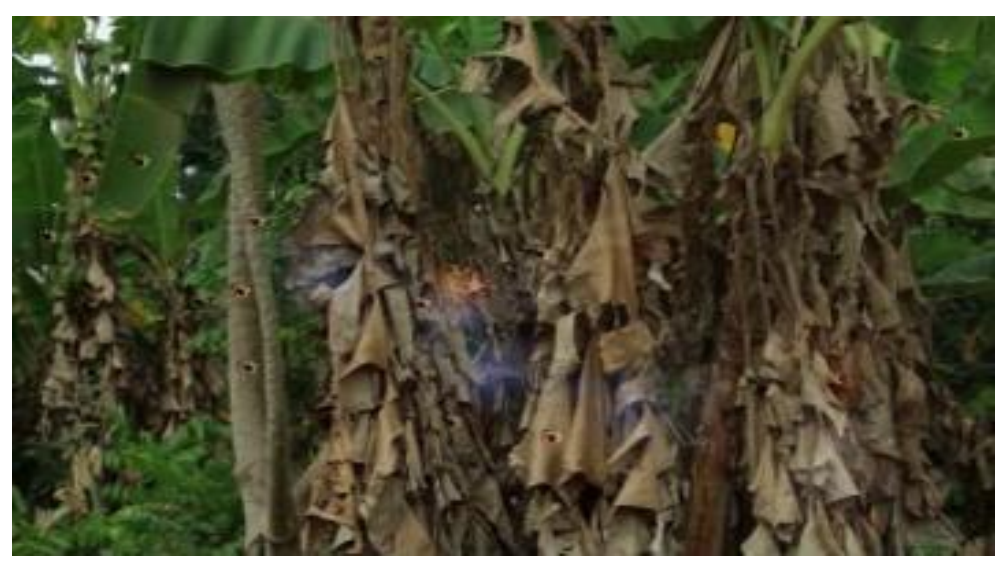

\section{Obi Olisa's No Mercy part two (41:00): village farm}

Another issue in the environmentalism is the desire to preserve and protect plants and animal diversity not only in the community of the poor but in the society as a whole. In the image above, we see bananas and pawpaw trees being destroyed. Banana which is food that can sustain the villagers is being destroyed by Atuegu and his men. Pawpaw fruit can bee of good help to the villagers because it consumption can improve their health conditions. The destruction of these foodstuff forces the villagers to fight against Atuegu in orders to save food for their children. 


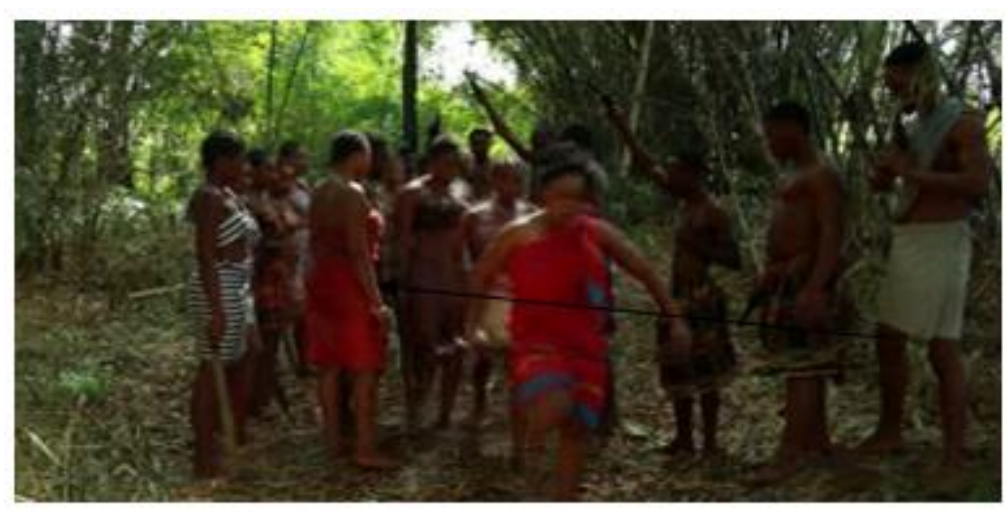

Women take up arms.

\section{Obi Olisa's No Mercy part two (55 minutes): in the bush}

Also, another aspect of the environmentalism of the poor is that both men, women and children stand up to defend their land from the wrongs that have been done on their land. Looking at the image above, we see that the women of Umuatu village are in line with this principle as they have taken up arms to join their men and fight to take back their land. This instance is employed to deconstruct the idea that we have about the place of women being in the kitchen. The producer wants to prove to the society that women also have the right to fight to preserve their environment. This is evident when Chisso (Chissoba) in the image says, the battle is not for men alone... we have to stand together and fight for what belong to us."

Ikenna Emma's The Liquid Black Gold portrayed the ways in which the Nzedeke community resists and coped with challenges from the oil company. Farming land was destroyed, fishing ground, their stream which served as the only source of drinking water for the whole community was polluted by the waste from the oil company. Those who they considers their elites that represent them before the government, the white men and their oil mining company squander the money allocated for the community development, even the money the set aside for the compensation of the youths. The youths resist all the intimidation and exploitation from the oppressors. 


\section{International Journal of Arts and Humanities}

ISSN: 2581-3102

Volume: 04, Issue: 01 "January 2020"

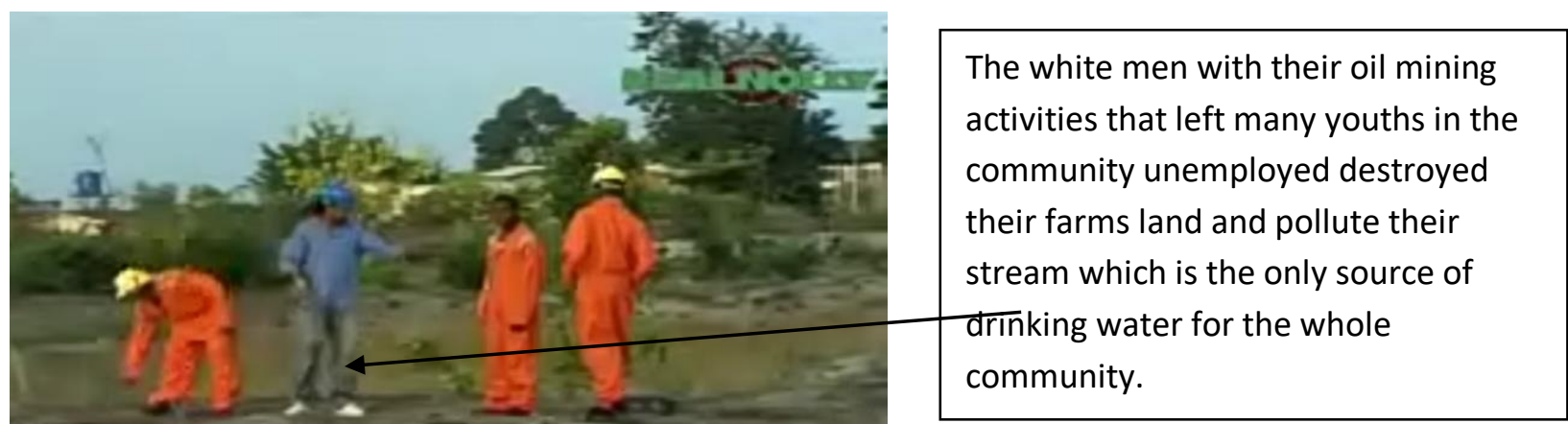

(1) The Liquid Black Gold. Part II (45:30)

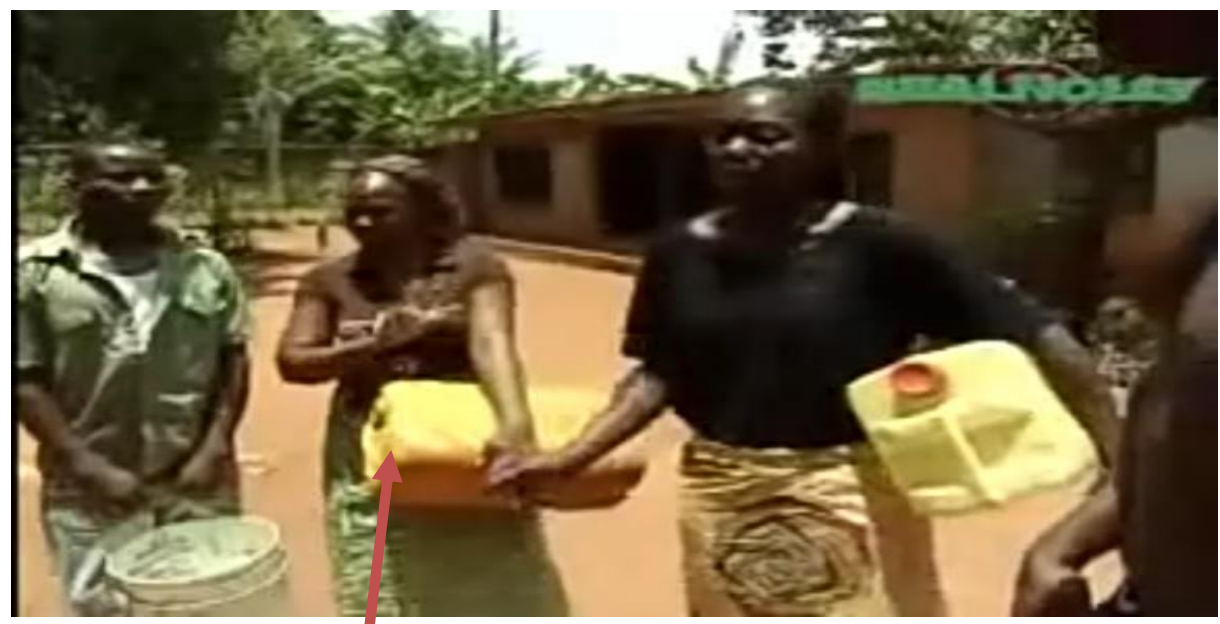

(b)

The villagers in search of drinking water due to the pollution of their stream by the oil mining company

PART $1 \quad 25: 23$ 


\section{International Journal of Arts and Humanities}

ISSN: 2581-3102

Volume: 04, Issue: 01 "January 2020"

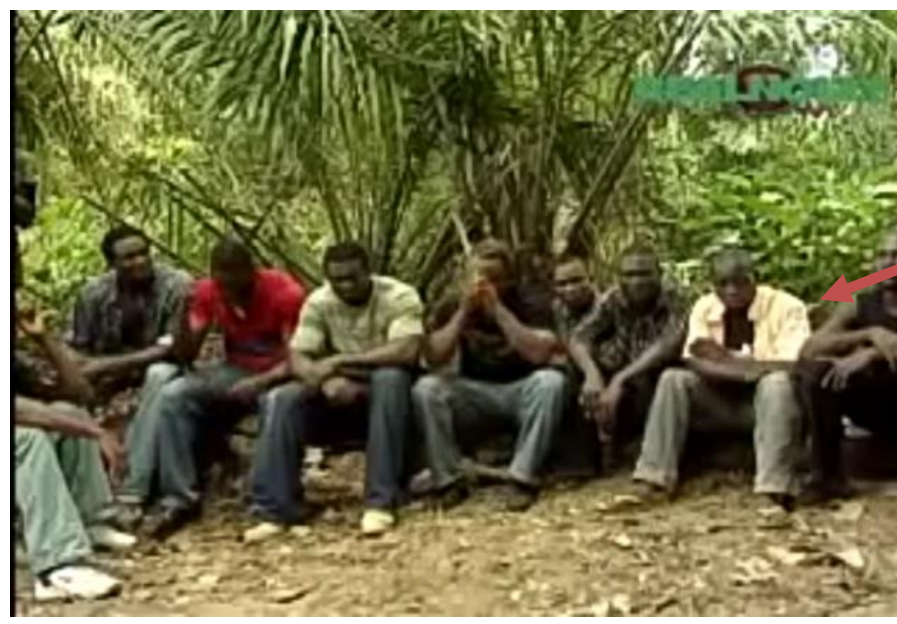

The youths out of frustration decided to organised themselves to cry out and defend their community from exploitation and destructions of their natural resources by their oppressors. PART 1 1:11:03

(C)

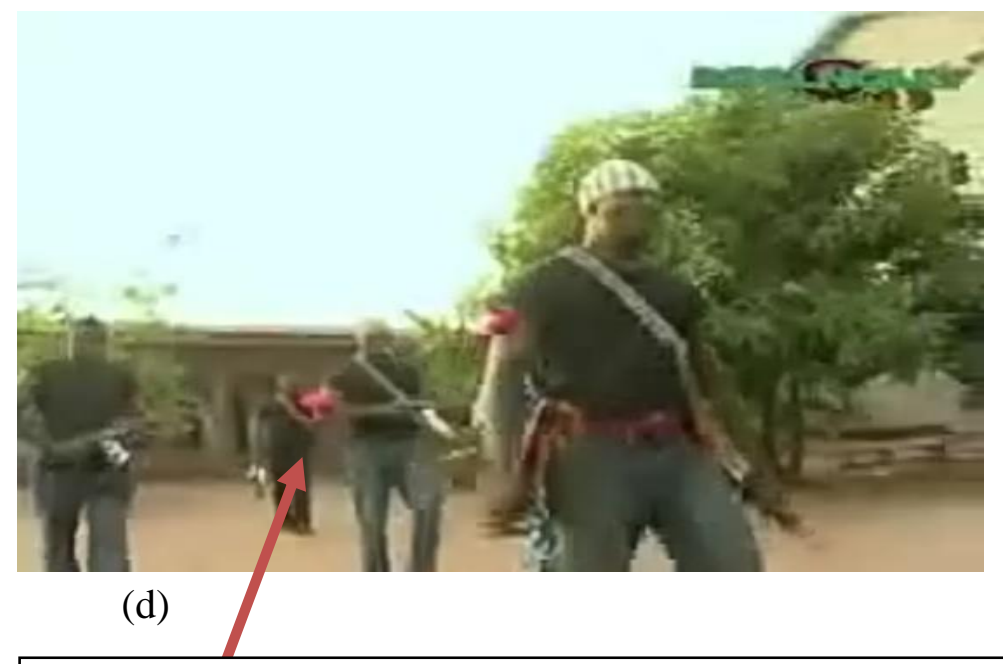

The youths picked up arms to fight and defend their community and their resources from exploitation.

Part 2 11:15 


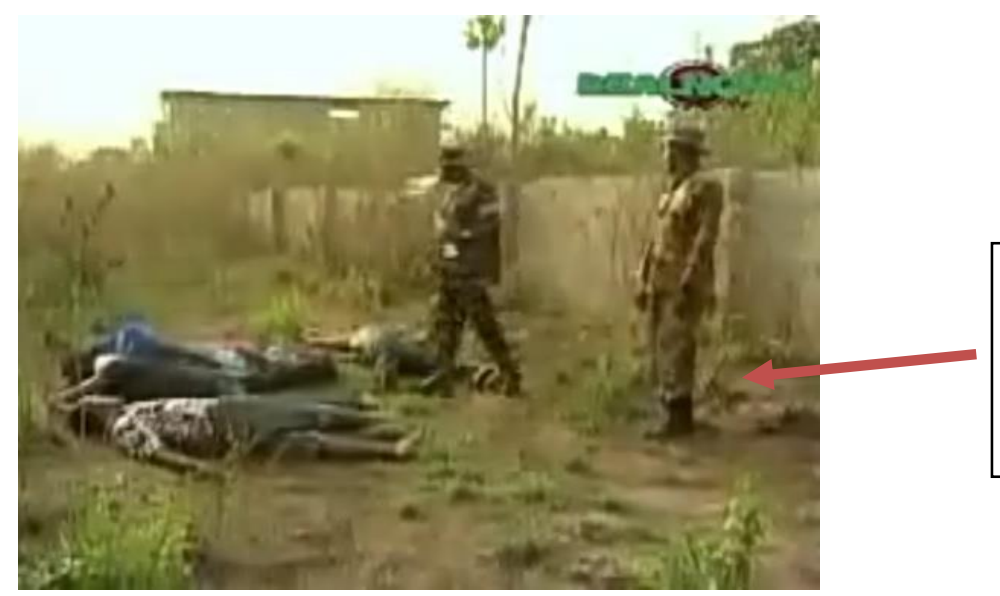

The killing of youths because they tried to resist the oppressors Part2 27:51

(e)

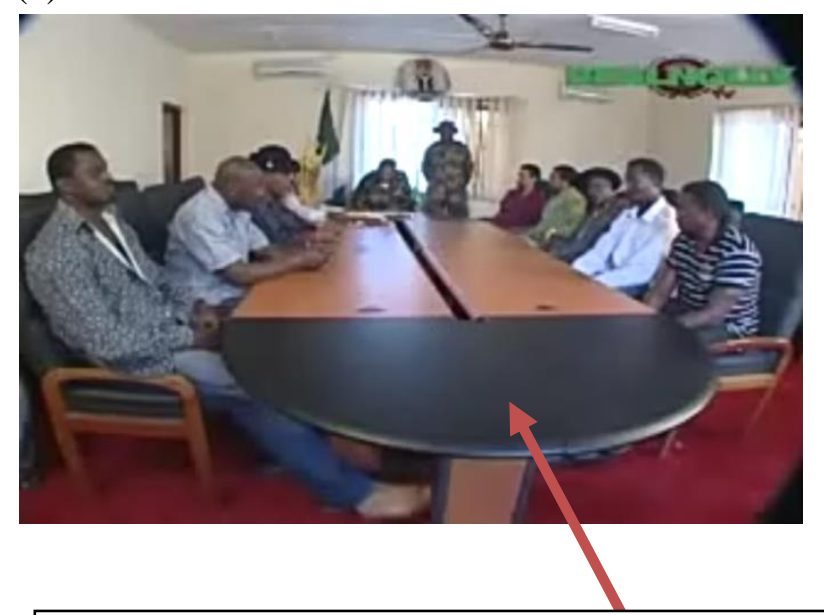

The three parties come to an agreement, the youths and the community compensation Chanel to them directly. All properties destroyed were paid, motor able roads constructed, good drinking water and social amenities provided to the community. PART2 1:30:16

\section{GENERAL CONCLUSION}

The representation of language, culture and environmental resilience, the Representation as it were, is an attempt to show the realities of the society. As such, in representing language it has been evident that it is represented at two levels, first as a medium of communication which is superficial and second as a cultural, which is deeply imbedded.

Besides being an alternative solution to integrate environmental education into the education system "nature" and "environment" are essential contexts for language education. Within the content of documentaries the use of any cultural element related to the target language (life style, 
International Journal of Arts and Humanities

ISSN: 2581-3102

Volume: 04, Issue: 01 "January 2020"

food, literature, dress etc.) has crucial value in developing environmental and cultural awareness in the language classroom.

This work examined language, culture and environmental resilience in "No Mercy" and "The liquid black gold". This work looked at the geographical location of Nigeria, Nollywood, statement of the problem, Purpose of study, research questions and hypotheses and motivation concerning the work. Chapter two looked at the theoretical frame and the review of literature. In chapter three, we brought out the method used to collect and analyse the data for this work.

And in chapter four, we presented the findings and analysed them to confirm or refute our hypothesis.

\section{REFERENCES}

Yunus Alyaz, Erkan Isigicok and Esim Gursoy (2016) The Impact of the Environmental Documentary Movies on Pre-service Journal of Education and Training Studies Vol. 5, No.1; January 2017

Dennis O'Neill (2016)_Culture Change . Greater Chicago Area.

Asogwa, Chika et al (2005), the representation of Nigerian indigenous culture in nollywood, Journal of scientific research and report, science domain international.

Ozele , M Anthony (2016), representation of cultural resilience and perceptions of religiosity in Nigerian movies and the Crisis of personal identity among Nigerian adolescent, new York, USA

Chinue Achebe (1958).Things fall Apart, William Heinemann ltd, Nigeria.

BAUDRILLARD, J. (1995). Simulacra and simulation. Ann Arbor: University of Michigan Press.

FUGLSANG, L. \& OLSEN, P. B. (Eds.) Videnskabsteori i samfundsvidenskaberne.

Frederiksberg, Roskilde Universitetsforlag.

Ikenna Emma (2013) The liquid black Gold, Nollywood, Nigeria.

Obi Olisa (2016) No Mercy. Prime World production.

Adesokan, Akin, "Nollywood and the idea of Nigerian cinema". Journal of African Cinemas 4.1 (202):81-98. 
International Journal of Arts and Humanities

ISSN: 2581-3102

Volume: 04, Issue: 01 "January 2020"

Harlem Brudtland (1987), Brudtland Report, world commission on environmentalism and development (WCED).

Martin Heddeger (19 $9^{\text {th }}$ century), destruction of philosophy. Kirno Sohochari.

Edmund Husserl (1990), Phenomenological deconstruction: Husserl's method of Abbau. J. C. Claude Evans journal of the British society for phenomenology 21(1):12-25.

J. Hillis Miller (1980), Deconstruction and Recovery of Transcendence. The university of Notre Dame.

Barbara Johnson (1994) The Wake of Dconstuction. Blackwell publisher;

Jacques Derrida, (1967) Of Grammatology. print media publisher.

Interview: Harold Bloom and Robert Moynihan (1983) Harold Bloom \& Robert Moynihan, Diachritics, vol. 13 No. 3, pp 57-68. The John Hopkins University Press.

SlovojZizek (1989), The Sublime Object of Ideology

Sidney Tarrow (1994). Power in movements, collective, action and politics. (Cambrigde University Press. 1994. Pp. X, 251. Cloth 59.95, Paper 17.95

Martinez- Alier (2008) Language of Valuation, economic and political weekly publisher, vol.43, No. 48 (Nov. 29-Dec. 5, 2008),pp.28-32

Guha and Martinez Alier (1997) Varieties of Environmentalism, Earthscan publications, 1997Nature-230pages

www.ejolt.org/2012/environmentalism-of-the-poor/.

http:/www.britannica.com/topic/deconstruction.

http:/en.m.wikipedia.org/wiki/Environmentalism.

www.thegreenmedium.com/blog/2015/9/2/a-brief-history-on-environmentalism.

http:/en.m.wikipedia.org/wiki/list-of-thinkers-influenced-by-deconstruction.

http:/link.springer.com/article/10.1186/s40728-016-0030-5. 